\title{
The Needs for Developing Clinical Supervision Model for Headmaster of Primary School in Gowa, Indonesia
}

\author{
M. Bachtiar \\ Department of Educational Management \\ Universitas Negeri Makassar, Indonesia \\ m.bachtiar@unm.ac.id
}

\author{
Wahira \\ Department of Educational Management \\ Universitas Negeri Makassar, Indonesia \\ wahiraart@yahoo.co.id
}

\author{
Andi Nurochmah \\ Department of Educational Management \\ Universitas Negeri Makassar, Indonesia \\ andi.nurochmah@gmail.com
}

\begin{abstract}
The main of this research was to developing clinical supervision model at headmaster of primary school in Gowa district. By developing clinical supervision model, the headmaster can get more benefits, they were in mastery competency, improving their abilities of understanding. This research was availabled of clinical supervision model. For getting this model the researcher used Research and Development (R\&D) model by Borg, Gall, and Sukmadinata, where modified three steps, they were: (1) the preliminary study phase as needs and contents analysis, (2) the development stage as design, development, and evaluation, and (3) the stage of the product for effectiveness testing as semi sumative evaluation. The stage of research that will be carried out in this study was the premilinary study phase. To know that the headmasters needs of clinical supervision model throught out by validity and effectiveness, the data take from the headmasters primary school in Gowa district. The result showed that the needs to developing the clinical supervision model by the headmasters, namely: the category of planning stage was very important, the category of the observation phase was very important, and the category of the evaluation and feedback stages was very important, by the models, they can increase their professionalisms.
\end{abstract}

Keyword: model, clinical supervision, headmaster

\section{INTRODUCTION}

Law of the Republic of Indonesia Number 14 of 2005 concerning Teachers and Lecturers, Chapter III Article 7 , is mandated that the teaching profession is a special field of work carried out based on the following principles: (1) having talents, interests, vocations, and idealism; (2) has a commitment to improve the quality of education, faith, piety and noble character; (3) has academic qualifications and educational background according to the field of work; (4) has the competencies needed in accordance with the field of duty; (5) has responsibility for carrying out professional tasks; (6) obtain an income determined in accordance with work performance; (7) have the opportunity to develop professionalism in a sustainable manner by lifelong learning; (8) has guaranteed legal protection in carrying out professional duties; and (9) have professional organizations that have the authority to regulate matters relating to the professionalism of teachers.

Improving the quality of education in school is carried out through supervision of the teachers as one of the spearheads of educational success. One form of supervision is teaching supervision which is carried out by using clinical approach to improve teachers' professionalism. Teacher is one of an important role in improving educational quality. Their roles are strategic learning planners, learning implementers, and learning evaluators. Remember how important the teachers' role, there should be a supervisor for them. Supervisor of education units should implement the ministerial regulation on oversight.

They should have competence in understanding both technique and method in supervision. The teacher is one component of educational resources requiring supervision services. The importance of educational supervision assistance to teachers is rooted deeply in people's lives. To carry out supervision requires strengths that can see sharply to problems in improving the quality of education, use sensitivity to understand it and not just use ordinary eye vision, because what it observes is not a concrete, visible problem, but requires sensitivity to the inner eye. A supervisor fosters improvement in academic quality related to efforts to create better conditions of learning academically, not merely physical material problems. when supervision is confronted with the performance and quality control of education by the unit supervisor, it certainly has a different mission from supervision by the school principal. This aims to provide services for school principals in developing teacher education institutions and facilitating school principals to be able to carry out institutional management effectively and efficiently.

The principal's clinical supervision program is arranged based on problem identification from teachers' perspective which was done last year such as teachers' coaching, evaluation, and also SWOT analysis for later to be included in the academic oversight plan program (RKA in Indonesian). the implementation of academic supervision by the principal is carried out in three stages, namely: a preliminary survey before conducting academic supervision, class visits to find out the course of learning, and reviewing the results of class visits and providing solutions to find out the course of learning, and reviewing the results of visits and providing a solution teat in overcoming problems faced by teachers; and Evaluation of the implementation of academic supervision by the 
school principal, including evaluating the job description and evaluating document evidence, by looking directly at the evidence of the tasks that have been carried out by the teacher then providing input if there are errors or deficiencies (Ajasan, 2016).

Educational supervision is carried out to improve learning activities. In general, supervision is carried out on the initiative of supervisors or principals. This is an effort to improve learning activities coming from the teacher concerned. The initiative to improve teaching skills that come from the teacher itself is very important to be developed. Educational supervision as an activity that is not separate from educational management activities needs to be pursued simultaneously and improved the quality of its implementation. Evidence that shows that supervision is part of national education management is that there is a special chapter on supervision in the National Education System Law No. 20 of 2003 which is regulated further by government regulations (Sudin, 2008). Teachers are not only required to teach, but also education. Professional and dedicated teacher guides are a must and for the success of their students. The teacher has a very important and decisive position. The teacher is the frontline in the implementation of the learning process in schools. Teachers are competent people who are responsible for the quality and meaningfulness of the learning process in the classroom. The teacher is a professional education with the main task of educating, teaching, guiding, directing, training, assessing, evaluating students (Winaryati, 2014).

Implementation of clinical supervision is very necessary in a good work climate in the initial meeting or planning, conducting observations of learning carefully, as well as analyzing the results of observations and providing feedback. teacher learning. Daryanto, et. al., (2015) mentions the different clinical supervision process steps, but actually the steps can be abstracted at three essential stages in the form of a process, namely: First the initial meeting or planning process, where this stage provides opportunities for teachers and supervisors to identify the teacher's main concern, then translate it into the form of observed behavior. The second stage is observation or teaching observation wherein this stage the teacher trains teaching behavior when teaching based on the component of skills requested by the teacher to be recorded. Supervisors can also make observations and record student behavior in class and interactions between teacher and students.

The three stages of the follow-up meeting, before the follow-up meeting is carried out the supervisor uses a preliminary analysis of the recorded observations made as material in this stage of discussion. In this case the supervisor must seek objective data, analyze and interpret cooperatively with the teacher about what has taken place in teaching. After conducting class visits and observations, the supervisor should be able to analyze the data he has obtained to be processed and reviewed which can be used as a guide and a reference for coaching and enhancing teachers further. Professional problems that have been identified need to be further studied in order to understand the true essence of the problem and its causal factors, then these problems are classified with a view to finding out which problems are faced by most teachers in the school or region. the determination and caution of the supervisor in weighing an issue will affect the success of the teacher's professional development process further.

According to the observation and unstructured interview which was done by researchers, the principal's clinical supervision was not going well. It was caused by principals did not pay attention to the standards. The goal of clinical supervision is to improve learning not teacher's personality. For this reason supervisors are expected to teach various skills to teachers which include: (1) observing skills, understanding the learning process analytically, (2) skills analyzing the learning process rationally based on clear and precise observational evidence, (3) skills in curriculum renewal, implementation and testing; (4) teaching skills (Tatang, 2016).

Usually, these goals are operationalized in smaller goals, namely specific teaching skills that have a very significant meaning in the teaching process. The goal of clinical supervision is often centered on; (1) personal awareness and confidence in carrying out teaching duties; (2) basic skills needed in teaching (Masaong, 2012). It is therefore expected that by developing this clinical supervision model the principal will conduct clinical supervision well because in general clinical supervision can be interpreted as a form of professional guidance given to teachers based on their needs through a systematic cycle aimed at helping the professional development of teachers, especially in teaching performance, based on observations and analysis of data carefully and objectively as a guide for changes in teaching behavior.

\section{METHOD}

This study used research and development procedural model because this study leads to describing the steps in producing product in the form of model and supporting device. There are ten steps in Borg dan Gall model. Sukmadinata (2006) then modified only three steps in research and development namely preliminary studies as needs and contents analysis, development steps as design, development, and evaluation, the effectiveness of the product testing phase as semi-summative evaluation.

The process of clinical supervision, the supervisor's behavior determines his success in helping develop the teacher. The focus of development lies in the function of implementing clinical supervision. The development of this clinical supervision model was designed with workshops and training activities which required a participant and instructor's interaction process using models and supporting packages in accordance with the objectives of the workshop and training. Clinical supervision aims to improve and enhance the teaching skills of teachers in the classroom. This clinical supervision relationship is the key to improving professional abilities so that teachers have the ability to improve themselves in carrying out the learning process.

The procedure for developing a clinical supervision model for primary school principals includes the stages of: (1) a preliminary study; (2) development stage; and (3) evaluation stages. This preliminary phase is 
carried out with the activity of reviewing the library needs to develop clinical supervision. Literature review is carried out by activities: (1) analyzing the clinical supervision process that has been conducted so far; (2) analyzing the sub-subject matter for the development of clinical supervision material; and (3) analyzing the source book to find the foundation of clinical supervising concept development in elementary school. The development phase is carried out by: (1) draft clinical supervision model; (2) focus group discussion; and (3) expert validation. The evaluation stages are carried out by: (1) implementing the model; (2) model revision; and (3) final model.

Gowa was chosen as the location of this study. There were 35 people as the subject of study for preliminary research from principal's work group (K3S in Indonesia) and elementary principals in Gowa district. The area for preliminary studies was elementary principal's clinical supervision competence in developing elementary teachers' competence. Observation sheet was used as data collection technique to know the needs of clinical supervision development which is given for teachers, supervisor, and principals.

\section{RESULT}

There were two main findings namely the needs of clinical supervision development model which is needed by elementary principals in Gowa district, and initial design form clinical supervision development model which is needed by elementary principal in Gowa district.

\section{Forms of Need for Development Clinical Supervision Model which is Needed by Elementary Principal in Gowa District}

This finding found that an overview of the needs of developing the supervision model needed by primary schools' principals in Gowa district namely preliminary needs, observation needs, and evaluation needs.

\section{Description of the indicators needs for the planning the development of clinical supervision models}

Research data regarding the need for development planning clinical supervision models based on a questionnaire obtained from questionnaire as mentioned creating familiar atmosphere, study a lesson plan, skill component, development of instrument observation, appropriate form of observation. Descriptive analysis can be seen in the Table 1 .

Table 1

Mean Score the Needs of Development Planning Model Clinical Supervision Aspect

\begin{tabular}{|c|c|c|}
\hline Category & Amount & Percentage \\
\hline Very important & 20 & $57,14 \%$ \\
\hline Important & 10 & $28,57 \%$ \\
\hline Less important & 5 & $14,28 \%$ \\
\hline Unimportant & 0 & $0 \%$ \\
\hline Total & 35 & $100 \%$ \\
\hline
\end{tabular}

In the planning needs in developing clinical supervision model, it is very important 20 or $57.14 \%$. Important categories of 10 or $28.57 \%$. Less important categories are 5 or $14.28 \%$. Unimportant categories are no one or $0 \%$. For more details can be seen in Figure 1.

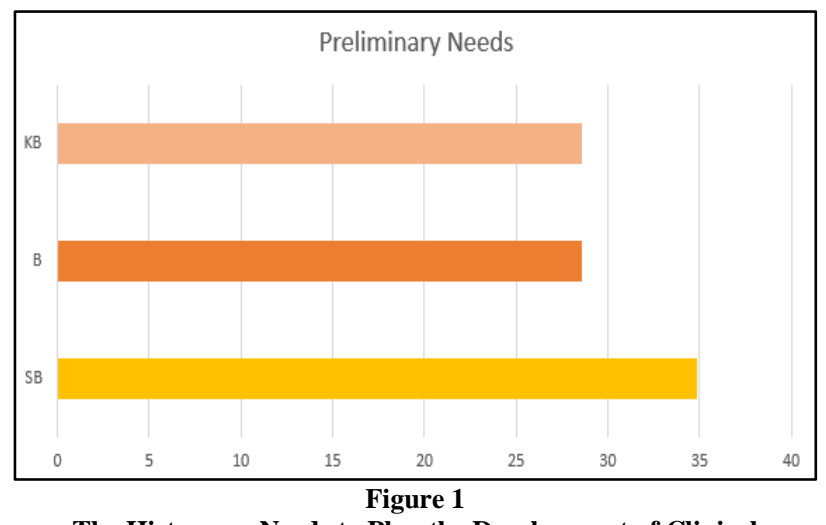

The Histogram Needs to Plan the Development of Clinical Supervision Models

Description Indicator Needs Evaluation of the Development of Clinical Supervise Models

Data on the results of research on the need for observation of developing a clinical supervision model based on a questionnaire obtained sub indicator data: (1) finding the strengths \& weaknesses of teachers; (2) identification of problems in learning; (3) knowing the needs of teachers; (4) teacher professional development; (5) completeness of the teaching and learning process; (6) self-confidence; (7) developing students' talents \& interests. Descriptive analysis of data as in Table 2.

Table 2

Mean Score of Observation Needs Aspect Development of Clinical Supervision Model

\begin{tabular}{|c|c|c|}
\hline Category & Amount & Percentage \\
\hline Very important & 15 & $42,85 \%$ \\
\hline Important & 10 & $28,57 \%$ \\
\hline Less important & 5 & $14,28 \%$ \\
\hline Unimportant & 5 & $14,28 \%$ \\
\hline Total & 35 & $100 \%$ \\
\hline
\end{tabular}

The observation needs in the implementation of the clinical supervision model category are very important 15 or $42.85 \% \%$. Important categories of 10 or $28.57 \%$. Less important categories are 5 or $14.28 \%$. Unimportant categories 5 or $14.28 \%$. For more details can be seen in Figure 2.

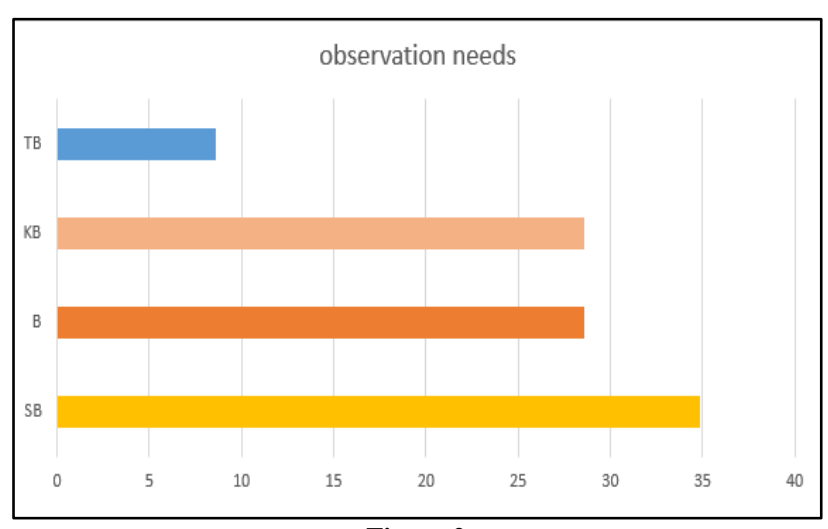

Figure 2

Histogram Observation Needs Development of Clinical Supervision Models 
Description of Indicators Need for Evaluation of Development of Clinical Supervision Models

Data on the results of research on the need for observation of developing a clinical supervision model based on a questionnaire obtained sub indicator data: (1) general impression of the teacher; (2) reviewing learning objectives; (3) teacher teaching skills, (4) impressions and achievement of learning targets, (5) reviewing the results of observations, and (6) determining improvement targets, descriptive data analysis as in Table 3 .

Table 3

Mean Score Aspect of Need for Evaluation of Development of Clinical Supervision Model

\begin{tabular}{|l|c|c|}
\hline \multicolumn{1}{|c|}{ Category } & Amount & Percentage \\
\hline Very important & 12 & $34,85 \%$ \\
\hline Important & 10 & $28,57 \%$ \\
\hline Less important & 10 & $28,57 \%$ \\
\hline Unimportant & 3 & $8,57 \%$ \\
\hline \multicolumn{1}{|c|}{ Total } & $\mathbf{3 5}$ & $\mathbf{1 0 0 \%}$ \\
\hline
\end{tabular}

On the observation needs in the implementation of the clinical supervision model the category is very important 12 or $34.85 \%$. Important categories 15 or $42.85 \%$. Less important categories are 5 or $14.28 \%$. Unimportant categories no one or $0 \%$. For more details can be seen in Figure 3.

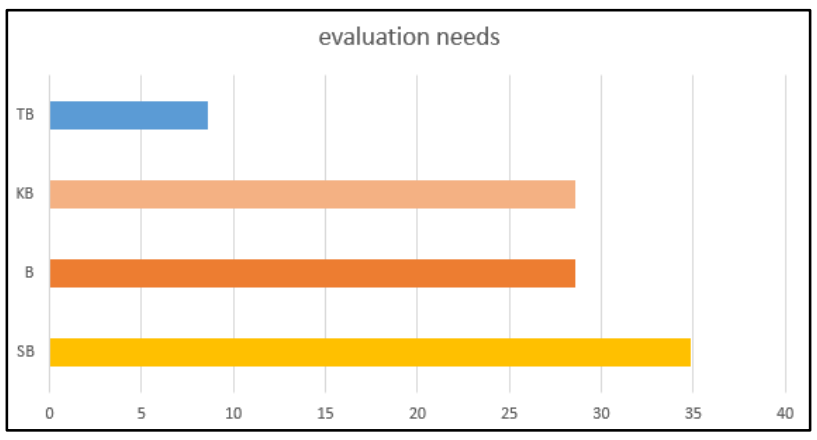

Figure 3

Histogram Evaluation Need for Development of Clinical Supervision Models

Form of Initial Design Development of Clinical Supervision Model Needed by Principals of Primary Schools in Gowa Regency

It is necessary to create teacher trust in supervisors, because this trust will affect the effectiveness of the initial meeting. This belief relates to the teacher's belief that supervisors pay attention to the teacher's interests or concerns. The preliminary meeting does not require a long time. Teaching observations, may feel very complex and difficult, and it is not uncommon for supervisors to experience difficulties. Thus, supervisors are required to use a variety of skills (Figure 4).

\section{DISCUSSIONS}

Based on the results described above, this section will discuss the results of the study in accordance with the indicators of achievement, as follows:

The Need for Developing Clinical Supervision Models Needed by School Principals in Gowa Regency

The results of this study indicate the need to develop a clinical supervision model that is needed by the principal, namely: the planning stage, the observation phase and the evaluation and feedback stage, these results increase teacher professionalism. For more details can be seen in Table 4.

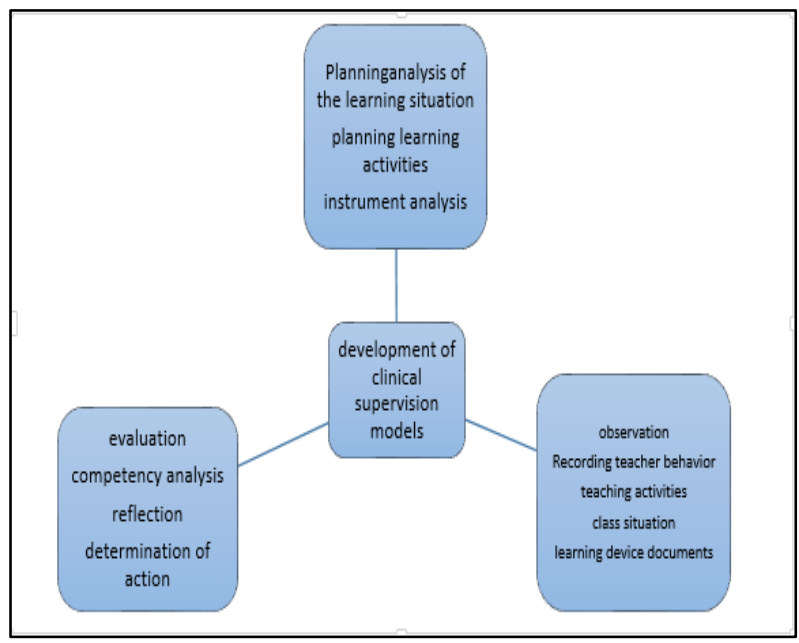

Figure 4

The Initial Draft Needs the Development of a Primary School Principal Supervision Model

Table 4

Mean Score Aspect of Need for Development of Clinical Supervision Model

\begin{tabular}{|l|c|c|}
\hline \multicolumn{1}{|c|}{ Needs Indicator } & Mean $(\mathbf{n}=\mathbf{3 5})$ & Category \\
\hline Plan & 4.27 & Very important \\
\hline Observe & 4.50 & Very important \\
\hline Evaluate & 3.50 & Very important \\
\hline \multicolumn{1}{|c|}{ Total } & $\mathbf{3 5}$ & Very important \\
\hline
\end{tabular}

In the planning needs of developing the clinical supervision model, the average score of 4.27 is very important category with 35 respondents. Indicators of the need for observation of the development of the clinical supervision model mean score of 4.50 are very important categories with 35 respondents. Indicators of the need for evaluation of the development of the clinical supervision model mean score of 3.50 are very important categories with 35 respondents. For more details can be seen in Figure 5.

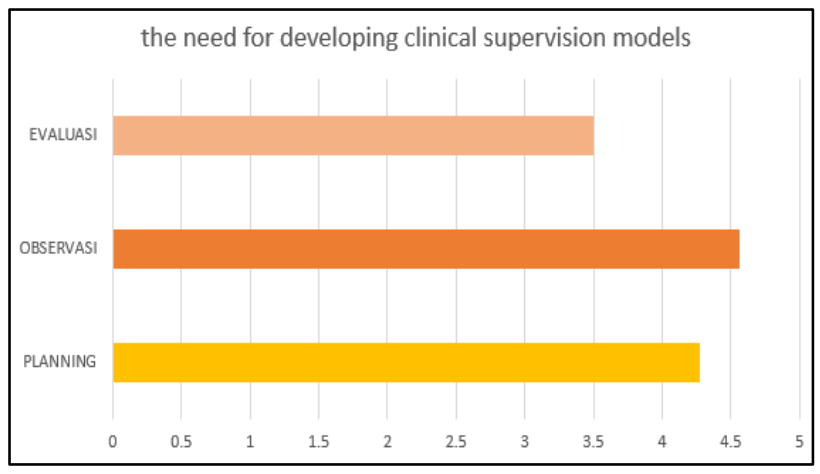

Figure 5

The Need for Developing Clinical Supervision Models for Primary School Principals in Gowa Regency

This finding is in line with Yudana (2014) who stated that Clinical supervision takes place in the form of face-to-face relationships between supervisors and teachers, the aim of clinical supervision is to develop 
teacher professionalism. Clinical supervision activities are emphasized on aspects of the teacher's attention and observations of teaching activities in the classroom, observations must be done carefully and in detail, analysis of observations must be done jointly between supervisors and teachers and the relationship between supervisors and teachers must be collegial rather than authoritative. Clinical supervision is a form of professional assistance given to teachers based on needs through a systematic cycle in planning, careful observation, and providing promptly objective feedback on the actual appearance of teaching to improve professionalism in teaching.

Form of Initial Design Development of Clinical Supervision Model Needed by Principals of Primary Schools in Gowa District

This study showed that the needs of development of clinical supervision model needed by principals of primary school is planning, observing, aevaluating, and giving feedback phase can improve teachers' professionalism. It is in the same argument with Walid (2012) who mentioned that clinical supervision has general objective to emphasize in the process of formation and development professional as the response of teachers' need related to their work. Pidarta (1999) revealed the same argument that bahwa clinical supervision characteristics include agreement between supervisors and teachers to be supervised about aspects of behavior to be improved, what is improved are aspects of teacher behavior in teaching and learning, there is an element of giving reinforcement to teacher behavior, there is the principle of cooperation between supervisors with teachers and supervision are carried out continuously.

In carrying out clinical supervision, it is necessary to have a good work climate in initial meetings, teaching observations, and feedback meetings. A very determining factor in the success of clinical supervision as a teaching supervision approach is the belief in the teacher that the supervisor's job is solely to help develop teacher teaching. Factors that influence the success or failure of supervising results are the community environment, the size of the school the principal is responsible for, the level and type of school, the condition of the teachers and staff available and the skills and expertise of the principal.

There are two assumptions that underlie clinical supervision practice. First, teaching is a very complex activity that requires careful observation and analysis through this observation and analysis, teaching supervisors will easily develop the teacher's ability to manage the learning process. Second, professional teachers who want to be developed want collegial rather than authoritarian ways.

The main purpose of this feedback meeting is to follow up what is seen by the supervisor, as an observer, towards the teaching and learning process. The discussion at this feedback meeting was emphasized on identifying and analyzing the similarities and differences between planned teacher and student behavior and the actual behavior of the teacher and student, as well as making decisions about what and how they should be done in relation to differences.

\section{CONCLUSION}

Based on the results of the research presented, there are two conclusions that can be drawn, namely: First, the need to develop a clinical supervision model needed by the principal: the category planning stage is very important, the category observation stage is very important, and the evaluation stage and category feedback are very important, because this can increase teacher professionalism. Secondly, the initial design form of developing the clinical supervision model needed by the principal: the planning stage, observation stages, and the evaluation and feedback stage, these results can increase teacher professionalism

\section{REFERENCES}

[1] Ajasan, N. U. 2016. Efektivitas Pelaksanaan Supervisi Akademik oleh Kepala Sekolah dalam Meningkatkan Kinerja Guru di SMK Negeri 1 Meulaboh. Aceh: Pascasarjana Unsyiah.

[2] Daryanto, Rachmawati, and Tutik. 2015. Supervisi Pembelajaran. Yogyakarta: Gava Media.

[3] Masaong, A. K. 2012. Supervisi Pembelajaran dan Pengembangan Kapasitas Guru. Bandung: Alfabeta.

[4] Pidarta, M. 1999. Pemikiran tentang Supervisi Pendidikan. Jakarta: Bumi Aksara.

[5] Sudin, A. 2008. Implementasi Supervisi Akademik terhadap Proses Pembelajaran di Sekolah Dasar Se Kabupaten Sumedang. Bandung: UPI.

[6] Sukmadinata, N. 2006. Metode Penelitian Pendidikan. Bandung: PT Remaja Rosdakarya.

[7] Tatang. 2016. Supervisi Pendidikan. Bandung: Pustaka Setia.

[8] Walid, M. 2012. Supervisi Pendidikan. Jember: CV Salsabila Putra Pratama.

[9] Winaryati, E. 2014. Kompetensi Pengawas dalam Supervisi Akademik pada SMP di Kota Semarang. Bandung: UPI.

[10] Yudana, M. 2011. Supervisi Akademik dalam Peningkatan Profesionalisme Guru. Singaraja: Undhiksha. 